\title{
Progress, problems and prospects of porcine pluripotent stem cells
}

\author{
Hanning WANG, Yangli PEI, Ning LI, Jianyong HAN (凶) \\ State Key Laboratory for Agrobiotechnology, College of Biological Sciences, China Agricultural University, Beijing 100193, China
}

\begin{abstract}
Pluripotent stem cells (PSCs), including embryonic stem cells (ESCs) and induced PSCs (iPSCs), can differentiate into cells of the three germ layers, suggesting that PSCs have great potential for basic developmental biology research and wide applications for clinical medicine. Genuine ESCs and iPSCs have been derived from mice and rats, but not from livestock such as the pig - an ideal animal model for studying human disease and regenerative medicine due to similarities with human physiologic processes. Efforts to derive porcine ESCs and iPSCs have not yielded high-quality PSCs that can produce chimeras with germline transmission. Thus, exploration of the unique porcine gene regulation network of preimplantation embryonic development may permit optimization of in vitro culture systems for raising porcine PSCs. Here we summarize the recent progress in porcine PSC generation as well as the problems encountered during this progress and we depict prospects for generating porcine naive PSCs.
\end{abstract}

Keywords induced pluripotent stem cells, embryonic stem cells, pig, reprogramming

\section{Introduction}

Embryonic stem cells (ESCs) derived from early-stage mammalian embryos are pluripotent stem cells (PSCs) that can self-renew and differentiate into any adult cell type $[1,2]$. Such capacities have potential applications in animal breeding and clinical medicine, such as cell therapy for Parkinson's disease and spinal cord injury.

Efforts to derive authentic ESCs over the last three decades have been of variable success. Mouse ESCs (mESCs), first isolated from inner cell masses of

Received April 4, 2014; accepted April 16, 2014

Correspondence: hanjy@cau.edu.cn blastocysts, have been cultured on feeder cells secreting cytokines for self-renewal and pluripotency. These cell lines can be expanded in an undifferentiated state and differentiate into endoderm, mesoderm and ectoderm cells in the form of in vitro embryoid bodies (EBs) and in vivo teratomas $[1,2]$. ESCs can even contribute to germline transmittable chimeras $[3,4]$ and fully form ESC mice via tetraploid complementation [5]. Thomson's group [6] derived human ESC lines from embryos with normal karyotypes and the potential to develop into trophoblasts and three embryonic germ layers. Progress has also been made in other species, including pigs [7-9], cattle [7,1013], sheep [14,15], rabbits [16], horses [17], dogs [18], and cats [19], but these studies did not fulfill all characteristics of mESCs. Also, at this time, researchers have failed to derive genuine ESCs from domesticated ungulates such as pigs, cattle, goats, sheep and derivation of germline transmittable chimeric offspring has proven to be elusive in these species.

Ethical concerns have been raised regarding stem cells generated from human embryos, which must be destroyed for ESC generation, as well as issues regarding immune rejection. Fortunately, iPSCs that somatic cells can be reprogrammed to PSCs by introducing four transcription factors, Oct4, Sox2, c-Myc and Klf4, provided a promising method to generate pluripotent cells similar to ESCs [20].

Recent iPSC developments suggest that these cells may help researchers overcome problems with generating pluripotent cell lines in livestock such as the pig. Such cells would represent improvements over mouse ESCs/ iPSCs which have limitations (short life spans and frank physiologic differences from humans) for studying human disease.

Furthermore, PSCs can be used to create genetically modified animals for functional genomics studies. Here we depict advancements and problems with porcine PSCs and discuss prospects for deriving naive pluripotent cell lines in the pig, offering a foundation for facilitating the generation of bona fide porcine PSCs. 


\section{Generation of ESCs and iPSCs in pigs}

Putative porcine ESC-like cell lines have been reported since the first paper to describe derivation of mESCs [79,14,21-32]. However, it is difficult to maintain porcine PSCs renewal and in the naive state for many passages. Compared to the mESCs, porcine ESC-like cells are not genuine ESCs that fulfill all pluripotency standards. Also, the optimal porcine embryonic stages and the culture systems for deriving ESCs/iPSCs have not been well described.

The pig is an excellent preclinical model for studying human diseases because of its similarities with human in physiology and anatomy. In the past 30 years, many laboratories have generated porcine ESC-like cell lines from embryos [7-9,14,21-24,28-38]. However, porcine ESC-like cells were maintained in an epithelial-like state or in an EpiSC-like (Epiblast stem cell-like) state, instead of in a mESC-like state $[32,39]$. Blastocysts used to generate porcine ESC-like cell lines have been at various stages of development, including post-estrous days 5-6 [25,28] post-estrous days 7-9 [7,28], and embryonic days 7-10 [30]. Porcine uterine cells [9], embryonic fibroblasts [32] or STO cells $[8,9,32]$ have been used as feeder cells. ESClike cells derived from different stage-embryos have been established via either immune-surgery or mechanical dissection. Some putative porcine ESC lines were positive for alkaline phosphatase (AP) $[33,40]$ and some formed teratomas in vivo [30]. Other cells produced chimeric coat color animals without germline transmission [33]. However, passaging these for extended times like mESCs is difficult. Miyoshi and colleagues reported the isolation of putative ESCs from porcine blastocysts which were maintained in vitro for more than 30 passages. They also indicated that reconstructed embryos could develop into blastocysts in vitro [29], but the cells had flattened and epithelial-like morphology and did not form chimeras. Recently, porcine ESC-like cells have been reported to express pluripotent markers such as Oct4, Nanog, SSEA-4, TRA1-60, and TRA1-81, but teratomas have not been produced to date [21].

Recent iPS technology provides a new method to derive PSCs and various methods have been used for reprogramming somatic cells, including approaches with pluripotency-associated factors, recombinant proteins, synthetic microRNAs, and cocktails of diverse chemical compounds [20,41-45]. Yamanaka overexpressed exogenous genes for reprogramming by retroviruses $[20,46]$, and others have generated mouse or human iPSC using lentiviruses $[47,48]$ and inducible lentiviruses $[19,49]$. In 2013, Deng's team used chemically based reprogramming and this was independent of exogenous genes [42].

Mouse iPSCs have the same in vivo developmental ability as ESCs, so iPSCs may replace ESCs for animal breeding and clinical applications. Livestock iPSCs such as porcine iPSCs (piPSCs) are the first induced pluripotent stem cell line established from livestock [21,50-57] and these cells have been described by different research groups who used diverse strategies for reprogramming somatic cells to livestock pluripotent cells, such as piPSCs (Table 1), bovine iPSCs (Table 2), and iPSCs in sheep and goats (Table 3). To generate such cells, either human or mouse pluripotent factors Oct4, Sox2, c-Myc and Klf4 were combined. Other pluripotent factors such as Nanog and Lin 28 have been overexpressed in the reprogramming process to derive piPSCs with high quality and efficiency [57]. Combination pluripotent factors and microRNAs including miR-302a, miR-302b and miR-200c have been reported to improve the efficiency of porcine somatic cell reprogramming [65]. Lentiviral and retrovirally mediated reprogramming methods have been used more frequently to generate piPSCs $[50,51,52,55]$. Livestock iPSCs have only been derived from differentiated cells via overexpression of transcriptional mouse, human, or livestock factors. The piPSCs resembled ESC-like cells with respect to morphology, pluripotent gene expression, and in vivoformed teratomas, but they cannot form chimeras with germline transmission [21,50-57].

\section{Characteristics of porcine PSCs}

Mouse ESCs are defined as PSCs in the naive state, characterized by compact, round and dome-like colony morphologies that can produce chimeras with germline transmission and could fully form mESCs via tetraploid complementation. In addition, other PSCs are flattened monolayer colonies (referred to as primed state or EpiSClike state). Human ESCs (hESCs) and mouse epiblast stem cells (mEpiSCs) represent this type of ESCs. The naive or the primed state of PSCs affects their in vitro differentiation and in vivo developmental abilities, even their clinical application potential $[77,78]$.

Researchers generally agree that livestock PSCs chiefly have two different colony morphologies similar to mESCs or hESCs, but that they lack in vivo developmental potential. Also, porcine putative ESCs have been generated with features of pluripotent cells, such as an ESC-like morphology, high AP activity, and the ability to differentiate in vitro $[26,28,79]$. These porcine embryo-derived cells can differentiate spontaneously mediated by EBs and can be induced to differentiate chemically. Most EBs in suspension differentiated into ectodermal, endodermal, and mesodermal cell types [80]. When ESC-like cells were injected subcutaneously into nude mice, teratomas were obtained around the injection site on the back of the mouse [81]. EpiSC-like porcine putative ESCs from IVF, IVF aggregated, in vivo derived, and parthenogenetic embryos expressed Activin/Nodal and FGF2 signaling pathway genes in addition to pluripotent genes such as Oct4, Sox2, 
Table 1 Generation of piPSCs

\begin{tabular}{|c|c|c|c|c|c|c|c|c|}
\hline Species & Original cell & Factor & Morphology & Karyotype & Pluripotent marker & Differentiation & Chimera & Reference \\
\hline \multirow[t]{13}{*}{$\overline{\text { Pig }}$} & $\begin{array}{l}\text { Porcine } \\
\text { fetal } \\
\text { fibroblasts }\end{array}$ & $\begin{array}{l}\text { Human } \\
\text { OSKC }\end{array}$ & $\begin{array}{l}\text { Human } \\
\text { ESC-like }\end{array}$ & Normal & $\begin{array}{c}\text { Oct4/Sox2/Klf4/c-Myc/Nanog /TERT/AP } \\
\text { /SSEA-1 }\end{array}$ & $\begin{array}{c}\text { Embryoid } \\
\text { bodies/Terato- } \\
\text { mas }\end{array}$ & No & [51] \\
\hline & $\begin{array}{l}\text { Porcine } \\
\text { fetal fibroblasts }\end{array}$ & $\begin{array}{l}\text { Human/ } \\
\text { Mouse } \\
\text { OSKC }\end{array}$ & $\begin{array}{l}\text { Human } \\
\text { ESC-like }\end{array}$ & Normal & Oct4/Sox $2 /$ TERT/Lin28/AP/Rex1/SSEA-4 & $\begin{array}{l}\text { Embryoid } \\
\text { bodies/Terato- } \\
\text { mas }\end{array}$ & No & [50] \\
\hline & $\begin{array}{l}\text { Primary } \\
\text { ear fibroblasts/ } \\
\text { Bone-marrow } \\
\text { cells }\end{array}$ & $\begin{array}{c}\text { Human } \\
\text { OSKC } \\
/ \\
\text { OSKC } \\
\text { NL }\end{array}$ & $\begin{array}{l}\text { Human } \\
\text { ESC-like }\end{array}$ & Normal & $\begin{array}{c}\text { Oct } 4 / \mathrm{Nanog} / \mathrm{Sox} 2 / \operatorname{Lin} 28 \\
/ \mathrm{CDH} 1 / \mathrm{AP} / \mathrm{SSEA}-3 / \mathrm{SSEA}-4 / \mathrm{TRA} 1-60 / \\
\text { TRA1-81/Rex1 }\end{array}$ & $\begin{array}{l}\text { Embryoid } \\
\text { bodies/Terato- } \\
\text { mas }\end{array}$ & No & [58] \\
\hline & $\begin{array}{l}\text { Porcine mesench- } \\
\text { ymal stem cells }\end{array}$ & $\begin{array}{l}\text { Human } \\
\text { OSKC } \\
\text { NL }\end{array}$ & $\begin{array}{l}\text { Human } \\
\text { ESC-like }\end{array}$ & Normal & Oct $4 /$ Sox $2 /$ SSEA-4 & Embryoid bodies & Yes & {$[57,59]$} \\
\hline & $\begin{array}{l}\text { Porcine } \\
\text { adult fibroblasts }\end{array}$ & OSKC & $\begin{array}{l}\text { Human } \\
\text { ESC-like }\end{array}$ & Normal & Nanog/SSEA-4/TRA1-60 & $\begin{array}{l}\text { Embryoid } \\
\text { bodies/Terato- } \\
\text { mas }\end{array}$ & No & [60] \\
\hline & $\begin{array}{l}\text { Porcine } \\
\text { adult fibroblasts }\end{array}$ & Mouse SKC & $\begin{array}{l}\text { Human } \\
\text { ESC-like }\end{array}$ & Normal & $\begin{array}{l}\text { Oct } 4 / \text { Sox } 2 / \text { Nanog/AP/ } \\
\text { SSEA-4/ } \\
\text { TRA1-60/TRA1-81 }\end{array}$ & $\begin{array}{l}\text { Embryoid } \\
\text { bodies/Terato- } \\
\text { mas }\end{array}$ & No & [55] \\
\hline & $\begin{array}{l}\text { Minipig } \\
\text { fetal fibroblasts }\end{array}$ & $\begin{array}{l}\text { Human } \\
\text { OSKC }\end{array}$ & $\begin{array}{l}\text { Mouse } \\
\text { ESC-like }\end{array}$ & $\begin{array}{l}\text { Not men- } \\
\text { tioned }\end{array}$ & $\begin{array}{l}\text { Oct } 4 / \text { Sox } 2 / \text { Klf4/ } \\
\text { c-Myc/Nanog/ } \\
\text { SSEA-1/SSEA-4 }\end{array}$ & Embryoid bodies & No & [61] \\
\hline & $\begin{array}{l}\text { Porcine mesench- } \\
\text { ymal stem cells }\end{array}$ & $\begin{array}{l}\text { Pig } \\
\text { Oct4 } \\
\text { /Klf4 }\end{array}$ & $\begin{array}{l}\text { Mouse } \\
\text { ESC-like }\end{array}$ & $70 \%$ normal & $\begin{array}{l}\text { Oct } 4 / \mathrm{Nanog} / \mathrm{Klf} 4 / \mathrm{c}-\mathrm{Myc} \\
\text { /Bmp } 4 / \mathrm{bFGF} / \mathrm{AP}\end{array}$ & $\begin{array}{l}\text { Embryoid } \\
\text { bodies/Terato- } \\
\text { mas }\end{array}$ & No & [54] \\
\hline & $\begin{array}{l}\text { Porcine embryo- } \\
\text { nic fibroblasts }\end{array}$ & $\begin{array}{l}\text { Mouse } \\
\text { OSKC }\end{array}$ & $\begin{array}{l}\text { Mouse } \\
\text { ESC-like }\end{array}$ & Nomal & $\begin{array}{c}\text { Oct4/Nanog/Eras/Sox2/ } \\
\text { Lin28/Stella/SSEA-1/SSEA-3/SSEA-4 }\end{array}$ & $\begin{array}{l}\text { Embryoid } \\
\text { bodies/Terato- } \\
\text { mas }\end{array}$ & No & [62] \\
\hline & $\begin{array}{l}\mathrm{PFX} / \mathrm{NM} \\
/ \mathrm{SWF} / \mathrm{LFF} \\
/ \mathrm{PEF} / \mathrm{HH} \\
/ \mathrm{PEFL}\end{array}$ & $\begin{array}{l}\text { Mouse } \\
\text { /Human } \\
\text { /Porcine } \\
\text { OSKC }\end{array}$ & $\begin{array}{l}\text { Mouse } \\
\text { ESC-like }\end{array}$ & Normal & $\begin{array}{c}\text { Oct4/Nanog/ } \\
\text { SSEA-3/SSEA-4/AP }\end{array}$ & $\begin{array}{l}\text { Embryoid } \\
\text { bodies/Terato- } \\
\text { mas }\end{array}$ & No & [63] \\
\hline & $\begin{array}{l}\text { Porcine } \\
\text { fetal fibroblasts }\end{array}$ & $\begin{array}{l}\text { Human } \\
\text { OSKC } \\
\text { NL }\end{array}$ & $\begin{array}{l}\text { Human ESC- } \\
\text { like }\end{array}$ & Normal & $\begin{array}{l}\text { Oct } 4 / \text { Sox } 2 / \mathrm{Nanog} / \mathrm{AP} / \\
\text { SSEA-1 }\end{array}$ & $\begin{array}{c}\text { Embryoid } \\
\text { bodies/Terato- } \\
\text { mas }\end{array}$ & No & [64] \\
\hline & $\begin{array}{l}\text { Porcine } \\
\text { fetal fibroblasts }\end{array}$ & $\begin{array}{l}\text { OSKC } \\
/ \mathrm{miR}-302 \mathrm{a} \\
/ \mathrm{miR}-302 \mathrm{~b} \\
/ \mathrm{miR}-200 \mathrm{c}\end{array}$ & $\begin{array}{l}\text { Human } \\
\text { ESC-like }\end{array}$ & Normal & $\begin{array}{c}\text { Oct } 4 / \text { Sox } 2 / \mathrm{Klf} 4 / \mathrm{c}-\mathrm{Myc} / \mathrm{REX} 1 / \mathrm{NANOG} / \\
\text { SSEA-4 }\end{array}$ & $\begin{array}{c}\text { Embryoid } \\
\text { bodies/Terato- } \\
\text { mas }\end{array}$ & No & [65] \\
\hline & $\begin{array}{l}\text { Porcine adipose- } \\
\text { derived } \\
\text { stem cells }\end{array}$ & $\begin{array}{l}\text { Human } \\
\text { OSKC }\end{array}$ & $\begin{array}{l}\text { Mouse } \\
\text { ESC-like }\end{array}$ & Normal & $\begin{array}{c}\text { Oct4/Sox2/ NANOG/AP/ } \\
\text { SSEA-3/SSEA-4/ } \\
\text { TRA1-60/TRA1-81 }\end{array}$ & $\begin{array}{c}\text { Embryoid } \\
\text { bodies/Terato- } \\
\text { mas }\end{array}$ & No & [66] \\
\hline
\end{tabular}

Note: PFX, newborn porcine ear fibroblast; NM, mesenchymal cells form new born porcine bone marrow; SWF, embryonic porcine fibroblast; LFF, embryonic porcine fibroblast; PEF, porcine embryonic fibroblast; HH, adult pig era fibroblast; PEFL, porcine embryonic fibroblast.

Nanog [21], but teratomas could not be formed in vivo [21].

Porcine iPSCs were pluripotent due to their ability to differentiate into cell types representative of the three germ layers through both in vitro EBs and in vivo teratomas $[50,51,52,54,55,65]$. They had a normal karyotype, but pluripotent marker expression was not stable. For instance, SSEA-3 [51], SSEA-4, TRA1-60 and TRA1-81 [55] were positive in some iPS cell lines, whereas others reported negative gene expression [51]. Cell lines positive for Oct4 and AP staining were have been also described. A main problem with piPSCs was that exogenous genes were not silenced. Furthermore, so far known piPSCs did not have the ability to produce germline transmittable chimeras $[57,59]$.

\section{Main problems with porcine PSC}

piPSCs have been derived in various ways, but their 
Table 2 Generation of bovine iPS cells

\begin{tabular}{|c|c|c|c|c|c|c|c|c|}
\hline Species & Original cell & Factor & Morphology & Karyotype & Pluripotent marker & Differentiation & Chimera & Reference \\
\hline \multirow[t]{4}{*}{$\overline{\text { Cattle }}$} & $\begin{array}{c}\text { Bovine } \\
\text { fetal fibroblasts }\end{array}$ & $\begin{array}{l}\text { Bovine } \\
\text { OSKC }\end{array}$ & $\begin{array}{l}\text { Mouse } \\
\text { /Human } \\
\text { ESC-like }\end{array}$ & Normal & $\begin{array}{c}\text { Oct4/Sox2/Nanog/CDH1/Dppa3 } \\
\text { /Stat3/Zfp42/Rex1/AP/SSEA-3 } \\
\text { /SSEA4/TRA1-60/TRA1-81 }\end{array}$ & $\begin{array}{l}\text { Embryoid bodies } \\
\text { /Teratomas }\end{array}$ & No & [67] \\
\hline & $\begin{array}{c}\text { Bovine } \\
\text { fetal fibroblasts }\end{array}$ & $\begin{array}{l}\text { Bovine } \\
\text { OSKC }\end{array}$ & $\begin{array}{c}\text { Mouse } \\
\text { ESC-like }\end{array}$ & Normal & $\begin{array}{l}\text { Sox2/Nanog/CDH1 } \\
\text { /Dppa-3/Dppa-4 } \\
\text { /Sall4/TERT/AP } \\
\text { /SSEA-1/SSEA-4 }\end{array}$ & $\begin{array}{l}\text { Embryoid bodies } \\
\text { /Teratomas }\end{array}$ & No & [68] \\
\hline & $\begin{array}{l}\text { Bovine } \\
\text { adult fibroblasts }\end{array}$ & $\begin{array}{l}\text { Human } \\
\text { OSKCN }\end{array}$ & $\begin{array}{l}\text { Mouse } \\
\text { ESC-like }\end{array}$ & Normal & $\begin{array}{c}\text { Oct4/Sox } 2 / \text { Nanog } \\
\text { /Klf4/c-Myc/Rex } 1 / \text { AP/SSEA-1 } \\
\text { /SSEA-4 }\end{array}$ & $\begin{array}{c}\text { Embryoid bodies } \\
\text { /Teratomas }\end{array}$ & No & [69] \\
\hline & $\begin{array}{c}\text { Bovine } \\
\text { fetal fibroblasts }\end{array}$ & $\begin{array}{l}\text { Human } \\
\text { Oct4 } \\
\text { Porcine } \\
\text { SK }\end{array}$ & $\begin{array}{c}\text { Human ESC- } \\
\text { like }\end{array}$ & Normal & Oct4/Nanog AP/SSEA-1 & $\begin{array}{l}\text { Embryoid bodies } \\
\text { /Teratomas }\end{array}$ & No & [70] \\
\hline
\end{tabular}

Table 3 Generation of ovine and caprine iPS cells

\begin{tabular}{|c|c|c|c|c|c|c|c|c|}
\hline Species & Original cell & Factor & Morphology & Karyotype & Pluripotent marker & Differentiation & Chimera & Reference \\
\hline \multirow[t]{4}{*}{ Sheep } & $\begin{array}{c}\text { Ovine } \\
\text { primary } \\
\text { ear fibroblast }\end{array}$ & $\begin{array}{l}\text { OSKCL/SV40 } \\
\text { large } \mathrm{T} / \mathrm{hTERT}\end{array}$ & $\begin{array}{c}\text { Mouse } \\
\text { ESC-like }\end{array}$ & Normal & $\begin{array}{c}\text { Oct4/Sox2/Nanog/CDH1/ Rex1/ AP } \\
\text { /Dppa-4/SSEA-1 } \\
\text { /TRA1-60/TRA1-81 }\end{array}$ & $\begin{array}{c}\text { Embryoid bodies } \\
\text { /Teratomas }\end{array}$ & No & [71] \\
\hline & $\begin{array}{l}\text { Ovine } \\
\text { fetal fibro- } \\
\text { blasts }\end{array}$ & Mouse OSKC & $\begin{array}{l}\text { Human } \\
\text { ESC-like }\end{array}$ & Normal & Oct4/Sox2/Nanog AP/SSEA-4 & $\begin{array}{c}\text { Embryoid bodies } \\
\text { /Teratomas }\end{array}$ & No & [72] \\
\hline & $\begin{array}{l}\text { Ovine } \\
\text { fetal fibro- } \\
\text { blasts }\end{array}$ & $\begin{array}{l}\text { Human } \\
\text { OSKC }\end{array}$ & $\begin{array}{l}\text { Mouse } \\
\text { ESC-like }\end{array}$ & Normal & Oct4/Sox $2 / \mathrm{Nanog} / \mathrm{AP}$ & $\begin{array}{l}\text { Embryoid bodies } \\
\text { /Teratomas }\end{array}$ & No & [73] \\
\hline & $\begin{array}{l}\text { Ovine } \\
\text { fetal fibro- } \\
\text { blasts }\end{array}$ & Mouse OSKC & & & $\begin{array}{c}\text { Nanog/AP } \\
\text { /SSEA-1/SSEA-4 }\end{array}$ & $\begin{array}{c}\text { Embryoid bodies } \\
\text { /Teratomas }\end{array}$ & $\begin{array}{c}\text { Yes } \\
\text { (PCR test) }\end{array}$ & [74] \\
\hline \multirow[t]{2}{*}{ Goat } & $\begin{array}{l}\text { Caprine pri- } \\
\text { mary } \\
\text { ear fibroblast }\end{array}$ & $\begin{array}{c}\text { Mouse } \\
\text { OSKCL/SV40 } \\
\text { large } \mathrm{T} / \mathrm{hTERT}\end{array}$ & $\begin{array}{l}\text { Mouse } \\
\text { ESC-like }\end{array}$ & Normal & $\begin{array}{l}\text { Oct4/Sox2/Nanog/CDH1/Rex1/ AP } \\
\text { /Sall4/SSEA1/TRA1-60/TRA1-81 }\end{array}$ & $\begin{array}{l}\text { Embryoid bodies } \\
\text { /Teratomas }\end{array}$ & No & [75] \\
\hline & $\begin{array}{c}\text { Fetal } \\
\text { primary } \\
\text { ear fibroblasts }\end{array}$ & Human OSKC & $\begin{array}{l}\text { Human } \\
\text { ESC-like }\end{array}$ & Normal & $\begin{array}{l}\text { Oct4/Sox } 2 / \text { Klf4 } \\
\text { /AP/Nanog }\end{array}$ & $\begin{array}{c}\text { Embryoid bodies } \\
\text { /Teratomas }\end{array}$ & No & {$[76]$} \\
\hline
\end{tabular}

morphologies have been inconsistent. As such, these cell lines cannot meet mESC's evaluation standards. During cell programming, somatic mitochondria and bioenergetics - from oxidative to glycolytic metabolism - can be remodeled when PSCs are generated [82]. Differences may exist in energetic metabolism between porcine pluripotent cells and mouse ESCs/iPSCs, as well, but at this time, it is unclear whether current media can meet the metabolic demands of porcine ESCs/iPSCs.

4.1 There is no optimal in vitro culture system for naive porcine PSCs

Maintenance of ESCs and iPSCs from pigs is problematic because little is known regarding optimal culture conditions for these cell lines. Thus, optimal cell culture protocols during iPSC generation may facilitate cell growth, reprogramming, and self-renewal [56]. According to various protocols for culturing mouse and human PSCs, porcine ESC-like cells and iPSCs are grown on feeder cells in medium supplemented with Dulbecco's Modified Eagle's Medium (DMEM), fetal bovine serum, nonessential amino acids (NEAA), $\beta$-mercaptoethanol and other compounds such as leukemia inhibitory factor (LIF) $[52,54,55,62,83]$, basic fibroblast growth factor (bFGF) $[50,51,57,84]$, stem cell factor (SCF), epidermal growth factor (EGF) and platelet-derived growth factor (PDGF) [85]. Although mouse and human ESCs can maintain pluripotency without feeder layers, mESCs require LIF and bone morphogenetic protein-4 (BMP4), whereas hESCs needed activin and bFGF [86]. mESC media with LIF and inhibitors was insufficient to elicit a response in human primed ESCs/iPSCs [87].

At present, LIF and bFGF are added to culture medium 
based on published papers. In mouse PSCs, LIF was involved in two important signaling pathways: JAKSTAT3 and PI3K-AKT to maintain PSC pluripotency. LIF was insufficient to maintain ungulate pluripotent cells in an undifferentiated state $[73,88]$, but its presence may inhibit cell differentiation [53]. VPA, SAHA and TSA as histone deacetylase inhibitors improved mouse cell reprogramming efficiency [89]. DNA methyltransferase inhibitors including 5-aza and RG108 [89-91] were reported to play a role in enhancing mouse iPSC generation.

LIF-based cell medium with specific protein kinase inhibitors can sustain piPSCs in the mESC state [92]. However, the JAK-STAT3 signaling pathway was not fully activated in porcine PSCs due to the lack of a LIF receptor in the pig $[93,94]$. The FGF signaling pathway may be present in the porcine epiblast: the presence of LIF, FGF or a combination of these was insufficient for porcine PSC growth and self-renewal, revealing that these growth factors cannot sustain porcine pluripotency [95]. According to published reports, inhibition of MEK $1 / 2$ and glycogen synthase-3 signaling pathways may contribute to supporting mouse ESCs/iPSCs pluripotency and selfrenewal. Porcine iPSCs, as well as bovine and ovine iPSCs, were also cultured in DMEM-based medium with inhibitors PD0325901 and CHIR9902 [52,67,73].

Compared with mouse and porcine SCNT (somatic cell nuclear transfer) embryos, genes coding for enzymes that regulate fatty acid biosynthesis were highly expressed at the early-embryo stages including the 4-cell and morula stage in normal porcine embryos. Gene ontology analysis suggested that mouse and porcine inner cell mass (ICM) had similar signaling pathways, such as for the cell cycle and cell division, and the transforming growth factor-beta (TGF-beta) receptor pathway for in vivo embryonic development and regulation of transcription. However, specific genes in porcine ICM were involved in unique pathways, including heat shock protein binding, and fatty acid beta-oxidation and metabolism. These unique regulation networks may be important in porcine early-embryo development [96].

Glycolysis provides energy for PSC growth and selfrenewal. During proliferation, pluripotent cells not only needed NADPH and ATP, but also required carbon, nitrogen and hydrogen products for cytoskeleton integrity $[97,98]$. Core transcription factors were related to STAT3 (signal reansducer and activator of transcription 3) signaling pathway controlled and regulated by glycolysis $[99,100]$. Thus, regulation of energetic metabolism must be considered when maintaining PSCs in the naive state. NEAA and L-glutamine were used in the medium as basic compositions. Metabolites of threonine in the medium also had important functions for ESC proliferation and selfrenewal [101].

Fatty acids store long-term energy supplies and are precursors for other molecules with multiple biologic functions. They may sustain porcine pluripotency as well [96]. Fatty acids may play an important role in the regulation of early embryo development somatic reprogramming. Polyunsaturated fatty acids were contributed to the process of oxidation reduction, and their metabolic products helped maintain "stemness" of pluripotent cells [102]. Arachidonic acid enhanced reprogramming efficiency during iPSC generation [103]. Also, butyrates in the medium improved Dppa5 expression and increased reprogramming efficiency and clone numbers. Shortchain fatty acids affected ESC pluripotency through epigenetic modification such as histone methylation and acetylation [104-106]. Therefore, culture systems, including a variety of compositions should be studied in-depth to facilitate the generation of genuine porcine PSCs.

4.2 No suitable standards exist for the evaluation of naive porcine PSCs

Pluripotency standards have been based on mouse or human ESCs/iPSCs, which express AP/Oct4/Sox2/Nanog/ SSEA-1/SSEA-3/SSEA-4, the potential to differentiate in vitro and in vivo, and the ability to produce chimeras. MicroRNA profiles and mitochondrial morphology can also be used as markers of the pluripotent stage [107]. However, recent porcine PSCs have not fulfilled the evaluation standards of mouse PSCs. The main reason may be the species diversity among pig, mouse and human.

The process from ICM to epiblast precursors in mouse is controlled by FGF, resulting in the repression of Nanog and the expression of Gata6, but the mechanism of human epiblast formation is unclear. In cattle, FGF has no effect in regulating Gata6 expression but it is reported to repress Nanog [108]. Studies suggest that Oct4 was expressed only in ICM during mouse preimplantation development $[96,109,110]$ and similarities in Oct4 expression patterns were identified between mouse embryos and in vivo porcine embryos, indicating that porcine Oct4 may have an effect on lineage segregation similar to that observed in mouse embryos. In the mouse, increased $C d \times 2$ expression occurred at the 8-cell stage and it predominated in the trophectoderm (TE) in early embryo-stage development. This also occurred in the pig, but $C d x 2$ expression was less than that in mouse. Nanog was expressed modestly but was not detected in the morula and blastocyst via immunofluorescence during porcine preimplantation development. Also, Gata6 and Sox2 expression in pigs was different from that observed in mice, suggesting that differences in the regulation and control of second lineage segregation events may exist between the mouse and pig [96]. Blastocysts did not express Nanog and Sox2 in porcine embryos on day 5-6 but later (about embryonic day 8.5) embryos expressed them [94]. Different from either mouse or primate, porcine embryos had its own expression pattern 
of Oct4, Nanog and Sox2. The hatched porcine embryo was independent on the expression profile compared to hatching mouse and human embryos [95].

Therefore, genes related to pluripotency and three germ layers differentiation are different during early embryo development, and pluripotency-associated genes in ESCs/ iPSC in vitro may differ in various species. It is of questionable value to assess porcine pluripotent cells according to the standards of mouse ESCs/iPSCs pluripotency.

\section{Perspectives and conclusions}

Substantial efforts have been made to generate PSCs from livestock such as the pig during the last three decades. Many attempts should be done in different ways so as to generate genuine porcine pluripotent stem cells in the naive state (Fig. 1). Key regulators in porcine early-embryo development must be understood for successfully reprogramming somatic cells into iPSCs via overexpression of Yamanaka's factors and candidate genes. Also, screening and identifying small molecules and fatty acids (as well as other additives) for culture medium may be required. Finally, pluripotency standards must be incorporated such as self-renewal, differentiation potential, metabolic similarities between piPSCs and porcine early embryos, and chimeric offspring. mRNA profiles and mitochondrial metabolism may also require consideration for generating porcine naive PSCs. At this time, scientists can apply iPSC technology to convert somatic cells into PSC, differentiating them for the study of diverse diseases and treatments [111].

The ability to differentiate PSCs into disease-relevant cell types-neurons, hepatocytes and cardiomyocytesprovides an invaluable paradigm in drug development.

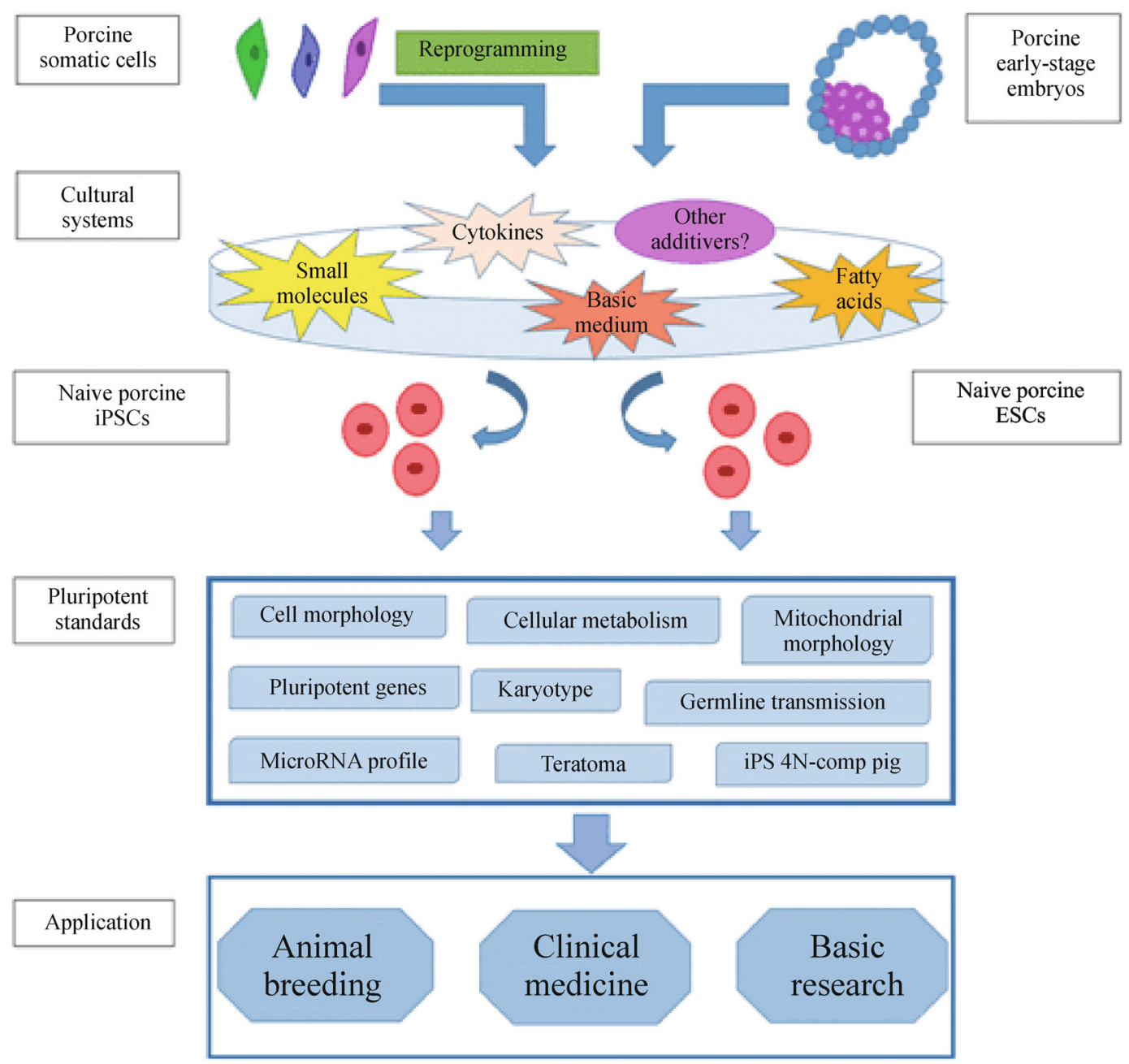

Fig. 1 Attempts to derive authentic piPSCs in the naive state. Chemicals, cytokines, fatty acids and other additives can be supplemented into the basic medium during the course of iPSC generation from somatic cells and ESC derivation from embryos. Various standards can be used to evaluate pluripotency of naive porcine PSCs. Then, these naive cells can be used in different applications such as animal breeding, basic research and clinical medicine 
High similarities between humans and pigs in physical and anatomical sides makes porcine PSCs attractive for investigation and as more is known about porcine earlystage embryo development, these cells will be easier to generate and use for clinical and basic research and animal breeding.

Acknowledgements This work was funded by the National Key Basic Research and Development Program of China (2010CB945404, 2011CBA01001 and 2009CB941003), the Chinese Universities Scientific Fund (2012RC014), and the National Thousand Talents Program of China.

Compliance with ethics guidelines Hanning Wang, Yangli Pei, Ning Li and Jianyong Han declare that they have no conflict of interest or financial conflicts to disclose.

This article is a review and does not contain any studies with human or animal subjects performed by the any of the authors.

\section{References}

1. Evans M J, Kaufman M H. Establishment in culture of pluripotential cells from mouse embryos. Nature, 1981, 292 (5819): 154-156

2. Martin G R. Isolation of a pluripotent cell line from early mouse embryos cultured in medium conditioned by teratocarcinoma stem cells. Proceedings of the National Academy of Sciences of the United States of America, 1981, 78(12): 7634-7638

3. Wang Z Q, Kiefer F, Urbánek P, Wagner E F. Generation of completely embryonic stem cell-derived mutant mice using tetraploid blastocyst injection. Mechanisms of Development, 1997, 62(2): 137-145

4. Eakin G S, Behringer R R. Tetraploid development in the mouse. Developmental Dynamics, 2003, 228(4): 751-766

5. Nagy A, Gócza E, Diaz E M, Prideaux V R, Iványi E, Markkula M, Rossant J. Embryonic stem cells alone are able to support fetal development in the mouse. Development, 1990, 110(3): 815-821

6. Thomson J A. Embryonic stem cell lines derived from human blastocysts. Science, 1998, 282(5391): 1145-1147

7. Evans M J, Notarianni E, Laurie S, Moor R M. Derivation and preliminary characterization of pluripotent cell lines from porcine and bovine blastocysts. Theriogenology, 1990, 33(1): 125-128

8. Notarianni E, Laurie S, Moor R M, Evans M J. Maintenance and differentiation in culture of pluripotential embryonic cell lines from pig blastocysts. Journal of Reproduction and Fertility-Supplement, 1990, 41: 51-56

9. Strojek R M, Reed M A, Hoover J L, Wagner T E. A method for cultivating morphologically undifferentiated embryonic stem cells from porcine blastocysts. Theriogenology, 1990, 33(4): 901-913

10. Saito S, Strelchenko N, Niemann H. Bovine embryonic stem celllike cell lines cultured over several passages. Roux's Archives of Developmental Biology, 1992, 201(3): 134-141

11. Talbot N C, Powell A M, Rexroad C E Jr. In vitro pluripotency of epiblasts derived from bovine blastocysts. Molecular Reproduction and Development, 1995, 42(1): 35-52

12. Van Stekelenburg-Hamers A E, Van Achterberg T A, Rebel H G, Fléchon J E, Campbell K H, Weima S M, Mummery C L. Isolation and characterization of permanent cell lines from inner cell mass cells of bovine blastocysts. Molecular Reproduction and Development, 1995, 40(4): 444-454

13. Cibelli J B, Stice S L, Golueke P J, Kane J J, Jerry J, Blackwell C, de León F A P, Robl J M. Transgenic bovine chimeric offspring produced from somatic cell-derived stem-like cells. Nature Biotechnology, 1998, 16(7): 642-646

14. Notarianni E, Galli C, Laurie S, Moor R M, Evans M J. Derivation of pluripotent, embryonic cell lines from the pig and sheep. Journal of Reproduction and Fertility-Supplement, 1991, 43: 255260

15. Meinecke-Tillmann S, Meinecke B. Isolation of ES-like cell lines from ovine and caprine pre-implantation embryos. Journal of Animal Breeding and Genetics, 1996, 113(1-6):413-426

16. Wang S, Tang X, Niu Y, Chen H, Li B, Li T, Zhang X, Hu Z, Zhou $\mathrm{Q}$, Ji W. Generation and characterization of rabbit embryonic stem cells. Stem Cells, 2007, 25(2): 481-489

17. Saito S, Sawai K, Minamihashi A, Ugai H, Murata T, Yokoyama K $\mathrm{K}$. Derivation, maintenance, and induction of the differentiation in vitro of equine embryonic stem cells. Methods in Molecular Biology, 2006, 329: 59-79

18. Hatoya S, Torii R, Kondo Y, Okuno T, Kobayashi K, Wijewardana V, Kawate N, Tamada H, Sawada T, Kumagai D, Sugiura K, Inaba $\mathrm{T}$. Isolation and characterization of embryonic stem-like cells from canine blastocysts. Molecular Reproduction and Development, 2006, 73(3): 298-305

19. Yu X, Jin G, Yin X, Cho S, Jeon J, Lee S, Kong I. Isolation and characterization of embryonic stem-like cells derived from in vivoproduced cat blastocysts. Molecular Reproduction and Development, 2008, 75(9): 1426-1432

20. Takahashi K, Yamanaka S. Induction of pluripotent stem cells from mouse embryonic and adult fibroblast cultures by defined factors. Cell, 2006, 126(4): 663-676

21. Park J K, Kim H S, Uh K J, Choi K H, Kim H M, Lee T, Yang B C, Kim H J, Ka H H, Kim H, Lee C K. Primed pluripotent cell lines derived from various embryonic origins and somatic cells in pig. PLoS ONE, 2013, 8(1): e52481

22. Tan G, Ren L, Huang Y, Tang X, Zhou Y, Zhou Y, Li D, Song H, Ouyang H, Pang D. Isolation and culture of embryonic stem-like cells from pig nuclear transfer blastocysts of different days. Zygote, 2012, 20(4): 347-352

23. Vackova I, Ungrova A, Lopes F. Putative embryonic stem cell lines from pig embryos. Journal of Reproduction and Development, 2007, 53(6): 1137-1149

24. Kim H S, Son H Y, Kim S, Lee G S, Park C H, Kang S K, Lee B C, Hwang W S, Lee C K. Isolation and initial culture of porcine inner cell masses derived from in vitro-produced blastocysts. Zygote, 2007, 15(01): 55

25. Li M, Ma W, Hou Y, Sun X F, Sun Q Y, Wang W H. Improved isolation and culture of embryonic stem cells from Chinese miniature pig. Journal of Reproduction and Development, 2004, 50(2): 237-244

26. Li M, Li Y H, Hou Y, Sun X F, Sun Q, Wang W H. Isolation and culture of pluripotent cells from in vitro produced porcine embryos. Zygote, 2004, 12(1): 43-48

27. Brevini T A L, Cillo F, Gandolfi F. 168 Establishment and 
molecular characterization of pig parthenogenetic embryonic stem cells. Reproduction, Fertility and Development, 2004, 17(2): 235

28. Li M, Zhang D, Hou Y, Jiao L, Zheng X, Wang W H. Isolation and culture of embryonic stem cells from porcine blastocysts. Molecular Reproduction and Development, 2003, 65(4): 429-434

29. Miyoshi K, Taguchi Y, Sendai Y, Hoshi H, Sato E. Establishment of a porcine cell line from in vitro-produced blastocysts and transfer of the cells into enucleated oocytes. Biology of Reproduction, 2000, 62(6): 1640-1646

30. Anderson G B, Choi S J, Bondurant R H. Survival of porcine inner cell masses in culture and after injection into blastocysts. Theriogenology, 1994, 42(1): 204-212

31. Hochereau-de Reviers M T, Perreau C P C, In vitro culture of embryonic disc cells from porcine blastocysts. Reproduction, Nutrition, Development, 1993, 33(5): 475-483

32. Piedrahita J A, Anderson G B, Bondurant R H. On the isolation of embryonic stem cells: comparative behavior of murine, porcine and ovine embryos. Theriogenology, 1990, 34(5): 879-901

33. Chen L R, Shiue Y L, Bertolini L, Medrano J F, BonDurant R H, Anderson G B. Establishment of pluripotent cell lines from porcine preimplantation embryos. Theriogenology, 1999, 52(2): 195-212

34. Iwasaki S, Campbell K H, Galli C, Akiyama K. Production of live calves derived from embryonic stem-like cells aggregated with tetraploid embryos. Biology of Reproduction, 2000, 62(2): 470475

35. Alberio R, Croxall N, Allegrucci C. Pig epiblast stem cells depend on activin/nodal signaling for pluripotency and self-renewal. Stem Cells and Development, 2010, 19(10): 1627-1636

36. Kim S, Kim J H, Lee E, Jeong Y W, Hossein M S, Park S M, Park S W, Lee J Y, Jeong Y I, Kim H S, Kim Y W, Hyun S H, Hwang W $\mathrm{S}$. Establishment and characterization of embryonic stem-like cells from porcine somatic cell nuclear transfer blastocysts. Zygote, 2010, 18(2): 93-101

37. Vassiliev I, Vassilieva S, Beebe L F S, Harrison S J, McIlfatrick S $\mathrm{M}$, Nottle M B. In vitro and in vivo characterization of putative porcine embryonic stem cells. Cell Reprogram, 2010, 12(2): 223230

38. Vassiliev I, Vassilieva S, Truong K P, Beebe L F S, McIlfatrick S $\mathrm{M}$, Harrison S J, Nottle M B. Isolation and in vitro characterization of putative porcine embryonic stem cells from cloned embryos treated with trichostatin A. Cell Reprogram, 2011, 13(3): 205213

39. Telugu B P, Ezashi T, Roberts R M. The promise of stem cell research in pigs and other ungulate species. Stem Cell Reviews, 2010, 6(1): 31-41

40. Moore K, Piedrahita J A. The effects of human leukemia inhibitory factor (hLIF) and culture medium on in vitro differentiation of cultured porcine inner cell mass (pICM). In Vitro Cellular \& Developmental Biology-Animal, 1997, 33(1): 62-71

41. Ma T, Xie M, Laurent T, Ding S. Progress in the reprogramming of somatic cells. Circulation Research, 2013, 112(3): 562-574

42. Hou P, Li Y, Zhang X, Liu C, Guan J, Li H, Zhao T, Ye J, Yang W, Liu K, Ge J, Xu J, Zhang Q, Zhao Y, Deng H. Pluripotent stem cells induced from mouse somatic cells by small-molecule compounds. Science, 2013, 341(6146): 651-654

43. Lin S L, Chang D C, Chang-Lin S, Lin C H, Wu D T S, Chen D T,
Ying S Y. Mir-302 reprograms human skin cancer cells into a pluripotent ES-cell-like state. $R N A, 2008,14(10)$ : 2115-2124

44. Judson R L, Babiarz J E, Venere M, Blelloch R. Embryonic stem cell-specific microRNAs promote induced pluripotency. Nature Biotechnology, 2009, 27(5): 459-461

45. Melton C, Judson R L, Blelloch R. Opposing microRNA families regulate self-renewal in mouse embryonic stem cells. Nature, 2010, 463(7281): 621-626

46. Takahashi K, Tanabe K, Ohnuki M, Narita M, Ichisaka T, Tomoda $\mathrm{K}$, Yamanaka S. Induction of pluripotent stem cells from adult human fibroblasts by defined factors. Cell, 2007, 131(5): 861-872

47. Blelloch R, Venere M, Yen J, Ramalho-Santos M. Generation of induced pluripotent stem cells in the absence of drug selection. Cell Stem Cell, 2007, 1(3): 245-247

48. Yu J, Vodyanik M A, Smuga-Otto K, Antosiewicz-Bourget J, Frane J L, Tian S, Nie J, Jonsdottir G A, Ruotti V, Stewart R, Slukvin I I, Thomson J A. Induced pluripotent stem cell lines derived from human somatic cells. Science, 2007, 318(5858): 1917-1920

49. Stadtfeld M, Maherali N, Breault D T, Hochedlinger K. Defining molecular cornerstones during fibroblast to iPS cell reprogramming in mouse. Cell Stem Cell, 2008, 2(3): 230-240

50. Esteban M A, Xu J, Yang J, Peng M, Qin D, Li W, Jiang Z, Chen J, Deng K, Zhong M, Cai J, Lai L, Pei D. Generation of induced pluripotent stem cell lines from Tibetan miniature pig. Journal of Biological Chemistry, 2009, 284(26): 17634-17640

51. Ezashi T, Telugu B P V L, Alexenko A P, Sachdev S, Sinha S, Roberts R M. Derivation of induced pluripotent stem cells from pig somatic cells. Proceedings of the National Academy of Sciences of the United States of America, 2009, 106(27): 10993-10998

52. Telugu B P, Ezashi T, Sinha S, Alexenko A P, Spate L, Prather R S, Roberts R M. Leukemia inhibitory factor (LIF)-dependent, pluripotent stem cells established from inner cell mass of porcine embryos. Journal of Biological Chemistry, 2011, 286(33): 2894828953

53. Brevini T, Pennarossa G, Maffei S, Gandolfi F. Pluripotency network in porcine embryos and derived cell lines. Reproduction in Domestic Animals, 2012, 47(Suppl 4): 86-91

54. Liu K, Ji G, Mao J, Liu M, Wang L, Chen C, Liu L. Generation of porcine-induced pluripotent stem cells by using OCT4 and KLF4 porcine factors. Cell Reprogram, 2012, 14(6): 505-513

55. Montserrat N, de Oñate L, Garreta E, González F, Adamo A, Eguizábal C, Häfner S, Vassena R, Belmonte J C I. Generation of feeder-free pig induced pluripotent stem cells without Pou5f1. Cell Transplantation, 2012, 21(5): 815-825

56. Gao Y, Guo Y, Duan A, Cheng D, Zhang S, Wang H. Optimization of culture conditions for maintaining porcine induced pluripotent stem cells. DNA and Cell Biology, 2014, 33(1): 1-11

57. West F D, Terlouw S L, Kwon D J, Mumaw J L, Dhara S K, Hasneen K, Dobrinsky J R, Stice S L. Porcine induced pluripotent stem cells produce chimeric offspring. Stem Cells and Development, 2010, 19(8): 1211-1220

58. Wu Z, Chen J, Ren J, Bao L, Liao J, Cui C, Rao L, Li H, Gu Y, Dai $\mathrm{H}$, Zhu H, Teng X, Cheng L, Xiao L. Generation of pig induced pluripotent stem cells with a drug-inducible system. Journal of Molecular Cell Biology, 2009, 1(1): 46-54

59. West F D, Uhl E W, Liu Y, Stowe H, Lu Y, Yu P, Gallegos- 
Cardenas A, Pratt S L, Stice S L. Brief report: chimeric pigs produced from induced pluripotent stem cells demonstrate germline transmission and no evidence of tumor formation in young pigs. Stem Cells, 2011, 29(10): 1640-1643

60. Montserrat N, Bahima E G, Batlle L, Häfner S, Rodrigues A M C, González F, Belmonte J C I. Generation of pig iPS cells: a model for cell therapy. Journal of Cardiovascular Translational Research, 2011, 4(2): 121-130

61. Hall V J, Kristensen M, Rasmussen M A, Ujhelly O, Dinnyés A, Hyttel P. Temporal repression of endogenous pluripotency genes during reprogramming of porcine induced pluripotent stem cells. Cell Reprogram, 2012, 14(3): 204-216

62. Fujishiro S H, Nakano K, Mizukami Y, Azami T, Arai Y, Matsunari $\mathrm{H}$, Ishino R, Nishimura $\mathrm{T}$, Watanabe $\mathrm{M}$, Abe $\mathrm{T}$, Furukawa Y, Umeyama K, Yamanaka S, Ema M, Nagashima H, Hanazono Y. Generation of naive-like porcine-induced pluripotent stem cells capable of contributing to embryonic and fetal development. Stem Cells and Development, 2013, 22(3): 473-482

63. Ji G, Ruan W, Liu K, Wang F, Sakellariou D, Chen J, Yang Y, Okuka M, Han J, Liu Z, Lai L, Gagos S, Xiao L, Deng H, Li N, Liu $\mathrm{L}$. Telomere reprogramming and maintenance in porcine iPS cells. PLoS ONE, 2013, 8(9): e74202

64. Kwon D J, Jeon H, Oh K B, Ock S A, Im G S, Lee S S, Im S K, Lee J W, Oh S J, Park J K, Hwang S. Generation of leukemia inhibitory factor-dependent induced pluripotent stem cells from the Massachusetts General Hospital miniature pig. BioMed Research International, 2013, 2013: 1-11

65. Ma K, Song G, An X, Fan A, Tan W, Tang B, Zhang X, Li Z. miRNAs promote generation of porcine-induced pluripotent stem cells. Molecular and Cellular Biochemistry, 2014, 389(1-2): 209218

66. Zhang Y, Wei C, Zhang P, Li X, Liu T, Pu Y, Li Y, Cao Z, Cao H, Liu Y, Zhang X, Zhang Y. Efficient reprogramming of naive-like induced pluripotent stem cells from porcine adipose-derived stem cells with a feeder-independent and serum-free system. PLOS ONE, 2014, 9(1): e85089

67. Huang B, Li T, Alonso-Gonzalez L, Gorre R, Keatley S, Green A, Turner P, Kallingappa P K, Verma V, Oback B. A virus-free polypromoter vector induces pluripotency in quiescent bovine cells under chemically defined conditions of dual kinase inhibition. PLoS ONE, 2011, 6(9): e24501

68. Han X, Han J, Ding F, Cao S, Lim S S, Dai Y, Zhang R, Zhang Y, Lim B, Li N. Generation of induced pluripotent stem cells from bovine embryonic fibroblast cells. Cell Research, 2011, 21(10): 1509-1512

69. Sumer H, Liu J, Malaver-Ortega L F, Lim M L, Khodadadi K, Verma P J. NANOG is a key factor for induction of pluripotency in bovine adult fibroblasts. Journal of Animal Science, 2011, 89(9): 2708-2716

70. Cao H, Yang P, Pu Y, Sun X, Yin H, Zhang Y, Zhang Y, Li Y, Liu Y, Fang F, Zhang Z, Tao Y, Zhang X. Characterization of bovine induced pluripotent stem cells by lentiviral transduction of reprogramming factor fusion proteins. International Journal of Biological Sciences, 2012, 8(4): 498-511

71. Bao L, He L, Chen J, Wu Z, Liao J, Rao L, Ren J, Li H, Zhu H, Qian L, Gu Y, Dai H, Xu X, Zhou J, Wang W, Cui C, Xiao L.
Reprogramming of ovine adult fibroblasts to pluripotency via drug-inducible expression of defined factors. Cell Research, 2011, 21(4): 600-608

72. Li Y. Lee A S, Zhang K H, Liu D J. Reprogramming of sheep fibroblasts into pluripotency under a drug-inducible expression of mouse-derived defined factors. PLoS ONE, 2011, 6(1): e15947

73. Liu, J., Balehosur D, Murray B, Kelly JM, Sumer H, Verma PJ. Generation and characterization of reprogrammed sheep induced pluripotent stem cells. Theriogenology, 2012. 77(2): 338-346

74. Sartori C, DiDomenico A I, Thomson A J, Milne E, Lillico S G, Burdon T G, Whitelaw C B. Ovine-induced pluripotent stem cells can contribute to chimeric lambs. Cell Reprogram, 2012, 14(1): 819

75. Ren J, Pak Y, He L, Qian L, Gu Y, Li H, Rao L, Liao J, Cui C, Xu X, Zhou J, Ri H, Xiao L. Generation of hircine-induced pluripotent stem cells by somatic cell reprogramming. Cell Research, 2011, 21 (5): 849-853

76. Song H, Li H, Huang M, Xu D, Gu C, Wang Z, Dong F, Wang F. Induced pluripotent stem cells from goat fibroblasts. Molecular Reproduction and Development, 2013, 80(12): 1009-1017

77. Nichols J, Smith A. Naive and primed pluripotent states. Cell Stem Cell, 2009, 4(6): 487-492

78. Ying Q L, Wray J, Nichols J, Batlle-Morera L, Doble B, Woodgett J, Cohen P, Smith A. The ground state of embryonic stem cell selfrenewal. Nature, 2008, 453(7194): 519-523

79. Horiuchi H, Tategaki A, Yamashita Y, Hisamatsu H, Ogawa M, Noguchi T, Aosasa M, Kawashima T, Akita S, Nishimichi N, Mitsui N, Furusawa S, Matsuda H. Chicken leukemia inhibitory factor maintains chicken embryonic stem cells in the undifferentiated state. Journal of Biological Chemistry, 2004, 279(23): 24514-24520

80. Brevini T A L, Cillo F, Gandolfi F. Establishment and molecular characterizition of pig parthenogenetic embryonic stem cells. Reproduction, Fertility and Development, 2005, 17(2): 235

81. Hochereau-de Reviers M T, Perreau C. In vitro culture of embryonic disc cells from porcine blastocysts. Reproduction, Nutrition, Development, 1993, 33(5): 475-483

82. Prigione A, Rohwer N, Hoffmann S, Mlody B, Drews K, Bukowiecki R, Blümlein K, Wanker E E, Ralser M, Cramer T, Adjaye J. HIF1alpha modulates cell fate reprogramming through early glycolytic shift and upregulation of PDK1-3 and PKM2. Stem Cells, 2014, 32(2): 364-376

83. Sanna D, Sanna A, Mara L, Pilichi S, Mastinu A, Chessa F, Pani L, Dattena M. Oct4 expression in in-vitro-produced sheep blastocysts and embryonic-stem-like cells. Cell Biology International, 2010, 34(1): 53-60

84. Yadav P S, Kues W A, Herrmann D, Carnwath J W, Niemann H. Bovine ICM derived cells express the Oct4 ortholog. Molecular Reproduction and Development, 2005, 72(2): 182-190

85. Saito S, Sawai K, Ugai H, Moriyasu S, Minamihashi A, Yamamoto Y, Hirayama H, Kageyama S, Pan J, Murata T, Kobayashi Y, Obata Y, Yokoyama K K. Generation of cloned calves and transgenic chimeric embryos from bovine embryonic stem-like cells. Biochemical and Biophysical Research Communications, 2003, 309(1): 104-113

86. Brevini T A, Antonini S, Pennarossa G, Gandolfi F. Recent 
progress in embryonic stem cell research and its application in domestic species. Reproduction in Domestic Animals, 2008, 43 (Suppl 2): 193-199

87. Hanna J, Cheng A W, Saha K, Kim J, Lengner C J, Soldner F, Cassady J P, Muffat J, Carey B W, Jaenisch R. Human embryonic stem cells with biological and epigenetic characteristics similar to those of mouse ESCs. Proceedings of the National Academy of Sciences of the United States of America, 2010, 107(20): 92229227

88. Blomberg L A, Telugu B P. Twenty years of embryonic stem cell research in farm animals. Reproduction in Domestic Animals, 2012, 47(Suppl 4): 80-85

89. Huangfu D, Maehr R, Guo W, Eijkelenboom A, Snitow M, Chen A E, Melton D A. Induction of pluripotent stem cells by defined factors is greatly improved by small-molecule compounds. Nature Biotechnology, 2008, 26(7): 795-797

90. Shi Y, Desponts C, Do J T, Hahm H S, Schöler H R, Ding S. Induction of pluripotent stem cells from mouse embryonic fibroblasts by Oct 4 and Klf4 with small-molecule compounds. Cell Stem Cell, 2008, 3(5): 568-574

91. Shi Y, Tae Do J, Desponts C, Hahm H S, Schöler H R, Ding S. A combined chemical and genetic approach for the generation of induced pluripotent stem cells. Cell Stem Cell, 2008, 2(6): 525528

92. Ezashi T, Telugu B P, Roberts R M. Induced pluripotent stem cells from pigs and other ungulate species: an alternative to embryonic stem cells? Reproduction in Domestic Animals, 2012, 47(Suppl 4): 92-97

93. Liu Y, Ma Y, Yang JY, Cheng D, Liu X, Ma X, West F D, Wang H. Comparative gene expression signature of pig, human and mouse induced pluripotent stem cell lines reveals insight into pig pluripotency gene networks. Stem Cell Reviews, 2014, 10(2): $162-176$

94. Hall V J, Christensen J, Gao Y, Schmidt M H, Hyttel P. Porcine pluripotency cell signaling develops from the inner cell mass to the epiblast during early development. Developmental Dynamics, 2009, 238(8): 2014-2024

95. Hall V J. Early development of the porcine embryo: the importance of cell signalling in development of pluripotent cell lines. Reproduction, Fertility and Development, 2012, 25(1): 94-102

96. Cao S, Han J, Wu J, Li Q, Liu S, Zhang W, Pei Y, Ruan X, Liu Z, Wang X, Lim B, Li N. Specific gene-regulation networks during the pre-implantation development of the pig embryo as revealed by deep sequencing. BMC Genomics, 2014, 15(1): 4

97. Vander Heiden M G, Cantley L C, Thompson C B. Understanding the Warburg effect: the metabolic requirements of cell proliferation. Science, 2009, 324(5930): 1029-1033

98. Zhang J, Nuebel E, Daley G Q, Koehler C M, Teitell M A. Metabolic regulation in pluripotent stem cells during reprogramming and self-renewal. Cell Stem Cell, 2012, 11(5): 589-595

99. Chen X, Xu H, Yuan P, Fang F, Huss M, Vega V B, Wong E, Orlov Y L, Zhang W, Jiang J, Loh Y H, Yeo H C, Yeo Z X, Narang V, Govindarajan K R, Leong B, Shahab A, Ruan Y, Bourque G, Sung W K, Clarke N D, Wei C L, Ng H H. Integration of external signaling pathways with the core transcriptional network in embryonic stem cells. Cell, 2008, 133(6): 1106-1117
100. Demaria M, Giorgi C, Lebiedzinska M, Esposito G, D'Angeli L, Bartoli A, Gough D J, Turkson J, Levy D, Watson C J, Wieckowski M R, Provero P, Pinton P, Poli V. A STAT3-mediated metabolic switch is involved in tumour transformation and STAT3 addiction. Aging, 2010, 2(11): 823-842

101. Wang J, Alexander P, Wu L, Hammer R, Cleaver O, McKnight S L. Dependence of mouse embryonic stem cells on threonine catabolism. Science, 2009, 325(5939): 435-439

102. Yanes O, Clark J, Wong D M, Patti G J, Sánchez-Ruiz A, Benton H P, Trauger S A, Desponts C, Ding S, Siuzdak G. Metabolic oxidation regulates embryonic stem cell differentiation. Nature Chemical Biology, 2010, 6(6): 411-417

103. Panopoulos A D, Yanes O, Ruiz S, Kida Y S, Diep D, Tautenhahn $\mathrm{R}$, Herrerías A, Batchelder E M, Plongthongkum N, Lutz M, Berggren W T, Zhang K, Evans R M, Siuzdak G, Belmonte J C I. The metabolome of induced pluripotent stem cells reveals metabolic changes occurring in somatic cell reprogramming. Cell Research, 2012, 22(1): 168-177

104. Ware C B, Wang L, Mecham B H, Shen L, Nelson A M, Bar M, Lamba D A, Dauphin D S, Buckingham B, Askari B, Lim R, Tewari M, Gartler S M, Issa J P, Pavlidis P, Duan Z, Blau C A. Histone deacetylase inhibition elicits an evolutionarily conserved self-renewal program in embryonic stem cells. Cell Stem Cell, 2009, 4(4): 359-369

105. Liang G, Taranova O, Xia K, Zhang Y. Butyrate promotes induced pluripotent stem cell generation. Journal of Biological Chemistry, 2010, 285(33): 25516-25521

106. Mali P, Chou B K, Yen J, Ye Z, Zou J, Dowey S, Brodsky R A, Ohm J E, Yu W, Baylin S B, Yusa K, Bradley A, Meyers D J, Mukherjee C, Cole P A, Cheng L. Butyrate greatly enhances derivation of human induced pluripotent stem cells by promoting epigenetic remodeling and the expression of pluripotencyassociated genes. Stem Cells, 2010, 28(4): 713-720

107. Ware C B, Nelsona A M, Mechamc B, Hesson J, Zhou W Y, Jonlin E C, Jimenez-Caliani A J, Deng X X, Cavanaugh C, Cook S, Tesarh P, Okada J, Margaretha L, Sperber H, Choi M, Blau C A, Treuting P M, Hawkins R D, Cirulli V, Ruohola-Bakera H. Derivation of naive human embryonic stem cells. Proceedings of the National Academy of Sciences of the United States of America, 2014 doi: 10.1073/pnas.1319738111 (first published online)

108. Gandolfi F, Pennarossa G, Maffei S, Brevini T A L. Why is it so difficult to derive pluripotent stem cells in domestic ungulates? Reproduction in Domestic Animals, 2012, 47(Suppl 5): 11-17

109. Loh Y H, Wu Q, Chew J L, Vega V B, Zhang W, Chen X, Bourque G, George J, Leong B, Liu J, Wong K Y, Sung K W, Lee C W H, Zhao X D, Chiu K P, Lipovich L, Kuznetsov V A, Robson P, Stanton L W, Wei C L, Ruan Y, Lim B, Ng H H. The Oct4 and Nanog transcription network regulates pluripotency in mouse embryonic stem cells. Nature Genetics, 2006, 38(4): 431-440

110. Bonnet A, Dalbies-Tran R, Sirard M A. Opportunities and challenges in applying genomics to the study of oogenesis and folliculogenesis in farm animals. Reproduction, 2008, 135(2): 119128

111. Teo A K, Wagers A J, Kulkarni R N. New opportunities: harnessing induced pluripotency for discovery in diabetes and metabolism. Cell Metabolism, 2013, 18(6): 775-791 